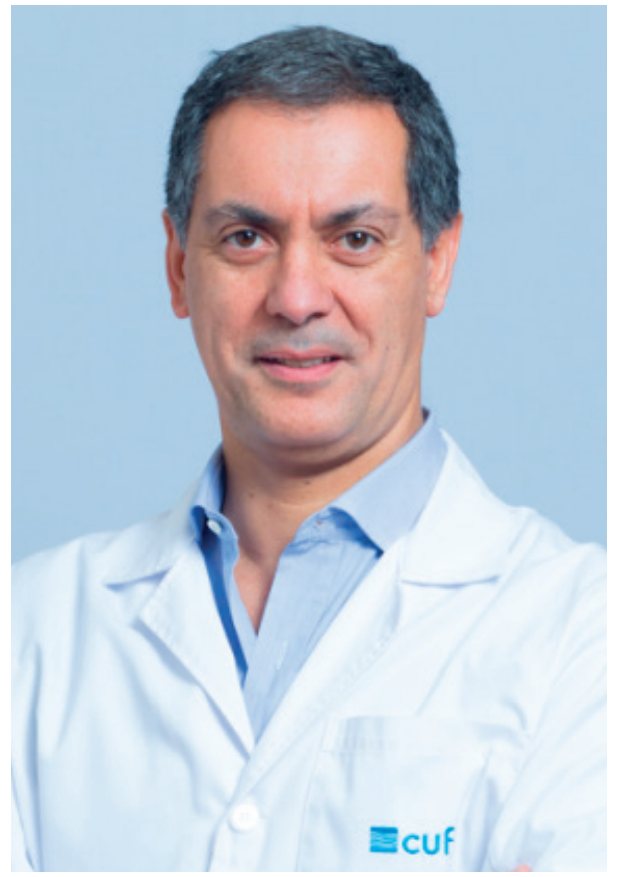

\title{
A Importância de Saber Comunicar
}

\section{The Importance of Knowing How to Communicate}

Armando Mansilha ${ }^{1}$

Qual o impacto que as diversas formas de comunicação (oral, escrita e não verbal) têm em circunstâncias clínicas específicas no relacionamento futuro com o doente e família e mesmo no prognóstico de evolução da doença?

Até que ponto a idade do doente, estado clínico prévio, contexto social, familiar e cultural interferem decisivamente nas suas expectativas e anseios, sendo que este pode, muito legitimamente, negar a gravidade da doença e resistir ao choque da informação recebida?

Qual a diferença, em termos de aceitação por parte do doente e da família, ser uma situação aguda no contexto de urgência em que o Médico era até então desconhecido ou tratar-se de uma evolução crónica, até potencialmente previsível, e o Especialista ser um interlocutor habitual, credor de uma confiança estabelecida nas múltiplas conversas prévias?

Apesar do resultado final poder ser em tudo aparentemente semelhante, todos estes diferentes contextos têm necessariamente implicações decisivas nas diversas formas de comunicação com o doente e respetiva família.

Os profissionais de saúde em geral, e naturalmente os Médicos em particular, são ética e legalmente obrigados a proporcionar aos seus doentes as informações completas e detalhadas que estes desejem saber sobre a sua doença, tratamento, evolução e prognóstico.

Na relação médico-doente, ao longo da história, foi-se verificando um paralelismo na forma como o médico encara o seu doente com a evolução do conceito de pessoa, na sua globalidade e complexidade. Histórica e culturalmente, particularmente nos países latinos, a relação médico-doente sempre foi entendida e considerada como uma relação desigual, de dependência, de poder de um (médico, ativo) sobre o outro (doente, passivo). O médico paternalista, omnipotente, mas não omnipresente, um ser superior e distante, com poder curativo, com ascendente técnico-científico e, não raras vezes, também sociocultural, que não tinha obrigação, necessidade, tempo ou vontade de informar, esclarecer ou explicar em detalhe. Esta atitude ajudou a estabelecer e perpetuar mitos sobre a comunicação das más notícias: "saber a verdade pode prejudicar, destruir a esperança, criar ansiedade ou depressão". Neste ambiente era o médico que decidia quando o doente podia e devia ter conhecimento de determinada informação clínica, que obviamente lhe dizia respeito e tinha consequências. Não contar a verdade ao doente para o "proteger" conduzia à mentira piedosa ou conspiração do 
silêncio, porque os outros profissionais de saúde não estavam naturalmente autorizados a fazê-lo. Era frequentemente referido não estar o doente preparado para "saber a verdade".

Foi já no fim do século XX que ocorreu progressivamente uma transformação conceptual na comunicação que faz com que hoje nos pareça inimaginável e absurdo a prática médica de outrora. O desenvolvimento da Bioética devido aos avanços progressivos e sustentados da sociedade civil, evidenciou de forma irreversível a necessidade de alterar substancialmente os princípios do direito à informação, da autonomia do doente e do consentimento informado e devidamente esclarecido, que impuseram ao médico, inicialmente de forma mais notória e consistente a nível dos países anglo-saxónicos, a obrigação ética e clínica de comunicar ao doente a verdade sobre a sua doença.

Coloca-se hoje um problema diferente na moderna medicina altamente tecnológica e sofisticada, particularmente a nível hospitalar e em hospitais maiores e altamente diferenciados, em que muitas decisões terapêuticas são baseadas em reuniões de Serviço, Departamento ou mesmo multidisciplinares. Embora sejam focadas no doente, apoiadas em níveis de evidência e nas recomendações emanadas pelas mais prestigiadas sociedades científicas internacionais, são não infrequentemente associadas a um anonimato institucional e uma dificuldade maior de identificar o "seu médico", com quem possa estabelecer um diálogo esclarecedor e informado, gerador de capital de confiança, não só sobre determinado exame específico ou procedimento médico-cirúrgico, mas sobre a doença como um todo, com presente e futuro.

Há uma absoluta necessidade de, a nível da formação pré-graduada e pós-graduada, mas também da vivência clínica diária, fomentar uma relação médico-doente personalizada e de promover uma comunicação com o doente e família bidirecional, franca, confortável, honesta, baseada na verdade e sensibilidade. Mas comunicar não pode ser, de forma simplista e redutora, um simples processo de transmitir ou debitar informação. Tem que ser um processo dinâmico, interativo, numa base de relação bidirecional, que implica e obriga a partilha de informação e de tempo, interação essa que terá que ser física, emocional e afetiva, mas não piedosa. Há que saber ouvir e compreender o doente e muitas vezes a família, mostrando interesse, disponibilidade e respeito. Um médico impreparado ou imaturo, colocando-se aqui a questão do papel dos internos de especialidade, pode ser psicologicamente devastador para o doente. E naturalmente não chega uma espécie de dom natural, uma vocação ou o simples, mas elementar bom senso e equilíbrio. Há que aprender, treinar, aperfeiçoar e validar continuamente competências clínicas de comunicação e relacionamento.

Comunicar "más notícias", como a impossibilidade de operar ou a necessidade de amputar é um dos atos mais difíceis do nosso quotidiano clínico, mas paradoxalmente muito secundarizado transversalmente na formação médica pré e pós-graduada. Não há uma metodologia única, mas qualquer que seja o modelo tem toda a vantagem em que seja feito de modo intensamente treinado e estruturado. Nesta preparação há que antecipar como e o que se vai informar. Não pode o Médico que tem de comunicar uma "má notícia" deixar de o fazer de forma pessoal e presencial, nunca por via telefónica ou apenas por escrito, particularmente por via informática. Tem que ter uma postura educada, cortês, cívica e utilizar uma linguagem clara e compreensível, não rebuscada ou muito técnica. Tem de ter tempo e revelar claramente disponibilidade, sem inoportunas interrupções que infelizmente tantas vezes se verificam em meio hospitalar. Tem de procurar que o espaço físico envolvente seja agradável, confortável, com boa luz e privacidade, sem estar focalizado no contemporâneo computador omnipresente. Ao iniciar o diálogo deve procurar perceber qual o conhecimento que o doente já tem da sua situação clínica, permitir-Ihe com abertura que este lhe possa colocar todas as questões, mesmo que possam parecer absurdas, compreender a sua perspetiva, estar atento ao seu comportamento emocional, à sua linguagem verbal e não-verbal, dosear e temporizar a informação, gerir os silêncios para dar tempo de a assimilar, responder com seriedade e pragmatismo, evitar respostas vagas ou minimizar a gravidade clínica, não gerar angústias desnecessárias, partilhar compreensão, motivar esperança e encorajar o doente a aceitar convictamente o consentimento informado e a anuir na adesão à proposta terapêutica. Só um doente bem informado e devidamente esclarecido ganha confiança no "seu médico" e na instituição, estabilidade emocional com ganho psicológico e uma atitude positiva na adesão à terapêutica. Só a verdade respeita os princípios éticos da confiança, da autonomia esclarecida e do direito à informação, essenciais na formalização necessária do consentimento informado e livremente assinado.

Um profissional de saúde tem que investir na sua aprendizagem, treino e melhoria de competências clínicas de comunicação verbal e não-verbal. No moderno conceito de medicina personalizada os alicerces que devem sustentar a comunicação clínica, um direito do doente, mas também e não de somenos importância um imperativo ético para o médico, devem ser a verdade e honestidade, confiança, prudência, bom senso e equilíbrio, personalização, disponibilidade, tempo, empatia e treino. 